\title{
A Comparative Study of the Effects of Electoral Institutions on Campaigns ${ }^{1}$
}

\author{
Laura Sudulich (1.sudulich@ @ent.ac.uk) \\ School of Politics and International Relations (University of Kent) \\ Siim Trumm (siim.trumm@swansea.ac.uk) \\ Department of Political and Cultural Studies (Swansea University)
}

\begin{abstract}
A long tradition of studies in political science has unveiled the effects of electoral institutions on party systems and parliamentary representation. Yet, their effects on campaign activities remain overlooked. Research in this tradition still lacks a strong comparative element able to explore the nuanced role that electoral institutions play in shaping individual-level campaigns during first-order parliamentary elections. We use data from a variety of national candidate studies to address this lacuna, showing that the electoral mobilisation efforts put in place by candidates are affected by the structure of the electoral institutions. Candidatecentred electoral systems propel higher mobilisation efforts, in terms of both campaign intensity and complexity. Moreover, we find that candidate-centred electoral systems shift the campaign focus towards individuals more than parties. By directly addressing the effects of electoral institutions on campaign behaviour, our study contributes to the wider debate on their role in promoting political engagement and mobilisation. The implications of our results concern the effects of electoral institutions on political competition, indicating that the extent to which electoral institutions impact upon it go well beyond what has been shown to date.
\end{abstract}

Keywords: Campaigns, electoral institutions, voter mobilisation, candidate studies

\footnotetext{
${ }^{1}$ An online appendix is available at http://whatever.org.
} 


\section{Introduction}

Electoral institutions matter for a multiplicity of features of political life. The literature on electoral systems - specifically on their systemic effects - has extensively explored the consequences of electoral mechanisms on proportionality, the number of existing parties, the representation of minorities and women, etc. ${ }^{2}$ Moreover, electoral institutions have been shown to shape the behaviour of voters, with regard to their likelihood of turning out to vote as well as vote choice. ${ }^{3}$ Finally, a significant body of research suggests that the behaviour of elected representatives is also affected by electoral mechanisms. ${ }^{4}$ Equally, the behaviour of parliamentary candidates should be shaped by the same institutions. In this article, we extend our understanding of electoral institutions and how they structure political competition by exploring their effect on the campaign activities of parliamentary candidates in the run up to first-order parliamentary elections. We do so by relying on a unique, pooled dataset of candidate studies from countries that employ a diverse range of electoral mechanisms.

To date, most studies of electoral campaigns during first-order parliamentary elections have been based on single systems, lacking an understanding of the role that electoral institutions play in the process. At the same time, contributions about the effects of electoral systems are concerned with their systemic effects much more than with their potential impact on the behaviour of political elites. In this study, we bridge these two traditions in order to enhance our understanding of elite behaviour,

\footnotetext{
${ }^{2}$ Farrell 2011; Gallagher and Mitchell 2005; Norris 2004; Norris and Inglehart 2001.

${ }^{3}$ Cox 1997; Fauvelle-Aymar and Lewis-Beck 2008; Karp et al. 2002.

${ }^{4}$ Alvarez and Sinclair 2012; Bowler and Farrell 1992; Farrell and Scully 2007.
} 
which fundamentally impacts on the extent to which citizens are exposed to campaign stimuli. Therefore, while directly addressing the scholarly literature on campaign behaviour, our study also contributes to the wider debate on the role of electoral institutions in promoting political engagement and mobilisation.

The novel data brought about by an extensive cross-sectional collection of candidate studies - we combine data from the Comparative Candidates Study (CCS) with compatible survey data from other countries - enable us to better grasp the multifaceted phenomena of political campaign. In particular, we disentangle the extent to which candidates' individual-level campaign effort varies under different electoral set ups. We do so by looking at the overall campaign effort put in place by candidates in the run up to first-order parliamentary elections, focusing on both its intensity as well as complexity. We find that under candidate-centred electoral institutions - for example, single member district plurality (SMD), open list proportional representation (PR), and single transferable vote PR (PR-STV) candidates' campaign effort tends to be more intense and complex than under partycentred mechanisms such as closed list PR. This - while intrinsically intuitive - goes against what has been found to be the case to date, ${ }^{5}$ and indicates that the impact of electoral institutions is more far-reaching than what the state of the art describes. Next to that, we shed further light on the relationship between individual candidates and their party by assessing how electoral institutions influence the candidates' campaign focus. Not surprisingly, the extent to which the candidates' campaign messages focus on themselves versus their party is also dependent on the structure of the electoral incentives, ceteris paribus. In addition, we find that candidates

\footnotetext{
${ }^{5}$ Bowler and Farrell 2011.
} 
campaign harder when the district magnitude is smaller. ${ }^{6}$ All in all, the amount and type of campaign stimuli that voters are likely to experience is closely related to the electoral institutions.

The article is organised as follows. In the next section, we survey the literature that we touch upon to guide our investigation. We then outline our expectations, describe the data and the operationalisation of the variables in use. This is followed by a presentation and discussion of the results of our empirical analysis. We conclude by summarising our findings and evaluating their implications.

\section{Electoral Institutions and Electoral Campaigns}

Partisan dealignment, societal and technological changes have jointly contributed to shaping the nature of electoral campaigns. As the number of floating voters ${ }^{7}$ as well as late-deciders ${ }^{8}$ who can be influenced and persuaded in the run up to an election keeps rising, so does the scholarly attention paid to campaign mobilisation. ${ }^{9}$

In defining the very concept of an electoral campaign, Farrell and Webb claim that there is an obvious relationship between the nature of electoral campaigns and

\footnotetext{
${ }^{6}$ For example, on average, candidates in Ireland spend approximately twice as much time on their campaign than their counterparts in the Netherlands. Whereas voters in both countries can cast their ballot for specific candidates, Irish constituencies are substantially smaller than the nation-wide constituency used in the Netherlands.

${ }^{7}$ Dalton 2008.

${ }^{8}$ McAllister 2002.

${ }^{9}$ Farrell 2006; Farrell and Schmitt-Beck 2002; Farrell and Webb 2000; Fieldhouse and Cutts 2009.
} 
institutional settings. ${ }^{10}$ Empirical tests to corroborate this claim are, as yet, very scarce. Evidence comes mostly from the voters' perspective: several studies suggest that electoral institutions can play a significant role in shaping the extent to which voters experience campaign stimuli. ${ }^{11}$ The claim that electoral institutions influence campaign mobilisation is essentially uncontested in this literature. Nevertheless, disagreement does exist on whether PR systems stimulate electioneering more than plurality, with reasonable arguments provided by both camps. On the one hand, PR systems involve a larger number of competitors, which tends to increase overall campaign activity and produce competitive contexts characterised by extensive campaign efforts. On the other hand, lower turnout - typical of plurality systems boosts the level of mobilisation in the run up to a vote. However, these two divergent theses share the common assumption that electoral institutions play a role in shaping campaign activity, which in turn affects electoral participation. Karp and colleagues systematically tested these competing hypotheses and disentangled the matter by relying on data from the Comparative Study of Electoral Systems (CSES) as well as national election studies. ${ }^{12}$ Consistently, across both types of data sources, they find that voters are more likely to experience higher degrees of campaign stimuli in candidate-based electoral systems. Further to this, the representation literature has provided evidence that plurality systems affect the style of representation by MPs, making them highly responsive to their constituents and somewhat less partisan. ${ }^{13}$ It is reasonable, therefore, to expect differences across electoral institutions to also

\footnotetext{
${ }^{10}$ Farrell and Webb 2000, 7.

${ }^{11}$ Karp, Banducci, and Bowler 2008.

12 Karp, Banducci, and Bowler 2008; Karp and Banducci 2007.

${ }^{13}$ Olivella and Tavits 2014.
} 
shape the behaviour of parliamentary candidates. After all, public representatives have been campaigning before the election and most likely will run again.

Conversely, the few studies that have investigated it from the candidates' perspective - in the context of the second-order European elections - have not found such an uncontested link between the electoral institutions and campaign effort. Bowler and Farrell explore the nexus between electoral systems and campaign activity by using 2006 MEP survey data, ${ }^{14}$ to find no evidence of electoral institutions affecting levels of campaign effort. ${ }^{15}$ They conclude that electoral institutions affect campaign goals, but fail to play a distinct role in structuring the campaign effort. Moreover, Giebler and Wüst, studying the 2009 European election, find no evidence that electoral systems shape the intensity of candidates' campaign effort (money or time), and only a partial indication that they influence candidates' choice of campaign tools. ${ }^{16}$

In sum, the claim that electoral institutions shape the campaign mobilisation effort is essentially contested and empirically less obvious than what is theorised. If the electoral architecture does indeed play a role in explaining variance in the campaign processes, the capacity of citizens to experience first-hand contact with political elites consequently varies, as does the nature of that contact. This has critical implications for political mobilisation and electoral participation.

\footnotetext{
${ }^{14}$ Bowler and Farrell 2011.

15 Their study, albeit offering valuable insights into the relationship between electoral institutions and campaign practices, focuses on second-order European elections and is limited to incumbents.

${ }^{16}$ Giebler and Wüst 2011.
} 


\section{Untangling the Relationship between Electoral Institutions and Campaigns}

We begin by identifying what might explain the existing inconsistency between the voter- and elite-side literatures. Conflicting findings on the effects of electoral institutions may be due to three reasons: here, we outline them and describe how our empirical strategy directly addresses them.

First, comparative studies of the elite side have, so far, looked at European elections where variation in electoral set ups is limited, as all European Union member states must use some form of proportional representation. Accounting for a greater degree of variation in electoral set ups might be, therefore, necessary to uncover the effects of electoral institutions on candidates' campaign behaviour. The CSS project, complemented with other compatible candidate surveys, covers a wide array of electoral mechanisms, including plurality systems. We implement a threefold strategy to systematically measure variation across the electoral systems and grasp their potential impact on campaign effort. First, we separately examine PR and SMD systems to explore whether candidates behave differently under these two broad electoral system families. This comparison will offer an initial indication of whether electoral institutions affect campaigning and electioneering. We then gauge more nuances of electoral institutions by using the index developed by Farrell and Scully's seminal study. ${ }^{17}$ This modified version of the Carey and Shugart, and Shugart's, index, ${ }^{18}$ simultaneously accounts for the role of (a) ballot access, (b) vote choice, and (c) district type in shaping the electoral environment in which candidates compete. It exposes more of the nuances of the various electoral set ups than a simpler PR versus

\footnotetext{
${ }^{17}$ Farrell and Scully 2007.

${ }^{18}$ Carey and Shugart 1995; Shugart 2001.
} 
SMD dichotomy. This is particularly relevant in light of the plethora of PR systems that are being used to elect MPs. Finally, we focus on the effect of district magnitude and address its interplay with vote choice. The assumption here is that candidates' campaign behaviour is influenced by whether voters can cast personal/preference votes, with the district size acting as a moderator. ${ }^{19}$

Second, measurement issues in the dependent variable may be responsible for the lack of findings from studies of the second-order European elections. For example, the analysis by Giebler and Wüst is limited to overall campaign effort in terms of the time and money spent by candidates, which does not necessarily account for the complexity of their campaign effort. In order to address this shortfall, we use a wider collection of information on the candidates' campaign effort. In addition to capturing the intensity of their campaign - the time spent campaigning -, we also account for the complexity of their campaign effort by exploring the range of communication channels used to reach potential voters. In other words, we gauge both the 'quantity' and the 'quality' of the candidates' campaign effort.

Finally, the mismatch between findings from the voter and elite side of the electoral equation may be due to the level of election that these studies have focused on. While the former are based on first-order parliamentary elections, the latter are, to date, limited to second-order European elections. Our study allows for the comparison of findings from the supply and demand sides within the same type of election, which is pivotal to resolving the unsettled incongruence.

\footnotetext{
${ }^{19}$ Carey and Shugart 1995.
} 


\section{Hypotheses}

Bowler and Farrell conclude that regardless of the electoral incentives in place, candidates work equally hard to get elected. ${ }^{20}$ This casts doubt on whether electoral institutions differ in their capacity to mobilise voters. We treat this claim as a null hypothesis.

Electoral campaigns are the effort put in place by candidates and parties to win votes. From a rational choice theory perspective, it is reasonable to imagine that the rules of the game affect the behaviour of the players: candidate-centred electoral mechanisms should put a stronger onus on individuals to promote their candidacy. The link between one's campaign activity - effort and focus - and electoral performance is simply more direct under these rules. The necessity to maximise personal reputation and profile, and to establish personal ties with constituents, is more salient and clear-cut in a system that rewards personal/preference votes.

This should be reflected in the amount of time and the type of resources that candidates invest in their campaign. For example, the utility of promoting one's candidacy can reasonably be seen as high for candidates in systems like the Irish PRSTV or the Estonian open list PR where all contenders have, in principle, an equal chance of being chosen by voters. Conversely, candidates in systems such as the Portuguese closed list PR are undoubtedly less likely to find the motivation to put in an equally high level of campaign effort as it is ultimately the party vote, rather than the personal vote, that shapes the electoral outcome. The link between an individual candidate's campaign effort and her electoral performance is simply not as clear-cut

\footnotetext{
${ }^{20}$ Bowler and Farrell 2011.
} 
in party-centred electoral systems as it is in candidate-centred ones. For example, thinking again about the Portuguese case, candidates at the top of their party list can reasonably expect to get elected irrespective of their own campaign effort. At the same time, there are no clear personal benefits associated with stronger campaign effort for candidates placed at the bottom of their party list. In party-centred systems, the utility of personal campaign effort is lower than in candidate-centred systems.

In addition to the effect associated with electoral rules, district magnitude is likely to affect campaign behaviour, on its own and in tandem with the institutional set up on candidate choice options. Identifying the target voters to contact and making one's presence visible is simpler in small districts. ${ }^{21}$ Therefore, lower district magnitude should encourage candidates to seek out direct contact with voters, while larger district magnitude should push them to rely more on their party image and exert less personal effort. However, the effects of the district size on the campaign effort are likely to be conditioned by whether voters cast their ballot for candidates or parties. If candidates compete for personal votes - that is, ballots are cast for candidates -, they simply cannot afford to rely merely on their party image, even when standing in a large constituency where establishing direct contact with voters is difficult. In these contexts, candidates face competition from co-partisans and are under more pressure to distinguish themselves from others. Therefore, the effect of district magnitude on campaign effort should be moderated by whether voters cast their ballot for parties or candidates. Based on these considerations, we formalise the following hypothesis:

H1: Electoral institutions significantly affect campaign effort in the following ways: (a) candidate-centred electoral systems promote greater campaign

\footnotetext{
${ }^{21}$ Bowler and Farrell 2011.
} 
effort than party-centred systems; (b) district magnitude has a negative effect on campaign effort; and (c) this is weaker in systems where voters cast their ballot for candidates as opposed to parties.

Another element of campaigning that is reasonably related to the structure of the electoral institutions is the focus of the candidates' message. All candidates seek to get out the vote and win voters' choice in the polling booth, but they can choose to do so by putting more (or less) emphasis on themselves (versus their party). Again, the rules of the game should impact the players' behaviour. Bowler and Farrell introduce "a conceptual distinction, reserving the term 'electioneering' for the kinds of acts that get people out to vote and using the term 'campaigning' to refer to the strategy at election time with regard to campaign goals (maximise party as opposed to individual vote share)". ${ }^{22}$ Building on this, we expand our assessment of candidates' campaign behaviour to explore whether electoral institutions influence the extent to which candidacy is promoted encompassing or bypassing the party.

While the expectations here are theoretically intuitive - party-oriented campaigns should prevail in party-centred electoral set ups like closed list PR, and candidatefocused campaigning should take place in systems such as open list PR and SMD -, empirical evidence is still unsystematic. Zittel and Gschwend's study of the German mixed system indicates that electoral incentives affect the candidates' campaign objectives, ${ }^{23}$ but is limited to one country with consequent narrow external validity. A series of case studies in Colomer's collection is offering further support for the

\footnotetext{
${ }^{22}$ Bowler and Farrell 2011, 683.

${ }^{23}$ Zittel and Gschwend 2008.
} 
underlying intuition, but does not provide comparable or comparative assessment. ${ }^{24}$ Counter-intuitively, Marsh finds that under the Irish PR-STV system - one of the most candidate-centred electoral mechanisms - campaigns are candidate-centred, as one would expect, but still remain "party-wrapped". ${ }^{25}$ Moreover, we still do not know how district magnitude affects - directly and conditionally - the link between electoral institutions and campaigning. Following above-mentioned considerations on how larger district magnitudes should push candidates to rely more on their party image, particularly where voters cast party-based (versus candidate-based) votes, we expect district magnitude to shape candidates' campaign focus. Formally, we test the following hypothesis:

H2: Electoral institutions significantly affect campaign focus in the following ways: (a) candidate-centred electoral systems promote a more candidatecentred campaign focus; (b) district magnitude has a negative effect on candidate-focused campaigning; and (c) this is weaker in systems where voters cast their ballot for candidates as opposed to parties.

\section{Data and Measures}

We evaluate our theoretical expectations on a unique collection of information on candidates running at first-order parliamentary elections. ${ }^{26}$ The CCS project, bringing together a wide range of national candidate studies and using a common core questionnaire to allow for cross-country comparisons, is the main source of this

\footnotetext{
${ }^{24}$ Colomer 2011.

${ }^{25}$ Marsh 2000.

${ }^{26}$ Countries covered in the study: Australia, Canada, the Czech Republic, Denmark, Estonia, Finland, Germany, Greece, Iceland, Ireland, Netherlands, Norway, Poland, Portugal, and Switzerland.
} 
information. To further maximise the array of electoral institutions under study, we combine the CCS data - version 2013AF2 - with additional survey data from countries not included in the project. ${ }^{27}$ As a result, we have information on the campaign activity of candidates from fifteen different countries. ${ }^{28}$ With the same key questions asked in a large pool of countries, it offers the first opportunity to extend the analysis of how electoral institutions influence the campaign behaviour of candidates to first-order parliamentary elections. ${ }^{29}$

\section{Dependent Variables}

In line with our theoretical approach, we identify survey measures that tap into the different strategic choices associated with electioneering and campaigning. Starting with the former, we implement a dual operationalisation. Our 'quantitative' measure of campaign effort describes how many hours per week each candidate spent on her

\footnotetext{
${ }^{27}$ These are Australia (2013), Estonia (2015), Ireland (2011), and Poland (2011).

${ }^{28}$ Note that we have information on campaign effort (time) from all fifteen countries, but the Czech Republic and Estonia are excluded from the analysis of campaign effort (complexity) and Canada is omitted from the analysis of campaign focus as survey questions are incomparable for those cases. Estimates from models relying on the constant sample of twelve countries where we have information on all dependent variables are, however, in line with the findings reported in the main text (see the online appendix Table A2).

${ }^{29}$ While candidates' self-reported behaviour is not immune from over-reporting, the possibility of this bias is systematic across all countries. Cross-validation with data from the Electoral Commissions is impracticable, as many countries in our analysis do not require candidates to officially report their expenses. Candidate studies still offer the best comparative data on candidates' campaign behaviour.
} 
campaign during the last month leading up to the election, ranging from 0 to $70 .^{30}$ This is preferred to campaign spending - which is extensively used as a proxy of campaign effort - as candidates were considerably less inclined to self-report their expenditure in the surveys. The number of hours - measured on an open scale reduces the amount of missing values and moderates concerns about misreporting, while still representing a highly adequate and widely used proxy for the overall intensity of one's campaign effort. ${ }^{31}$ To better gauge the concept of campaign effort, we complement the 'quantitative' measure with an index (ranging from 0 to 5) that captures the complexity of a candidate's campaign effort, tapping into its 'quality'. It describes how many campaign activities, from the following options, each candidate used as part of her campaign: i) canvassing, ii) direct mail, iii) online campaigning, iv) newspaper interviews, and v) TV interviews. These options not only maximise the amount of cases for analysis but also account for the different types of effort, including localised door-to-door direct contact with voters as well as both traditional and new media forms of campaign advertisement. This measure accounts for the complexity and richness of the campaign effort put in place by candidates in order to mobilise voters and seeks to provide evidence of whether voters are likely to experience various stimuli under different electoral rules.

The benefit of the dual operationalisation is twofold. First, the two measures tap into slightly different aspects of the candidates' campaign effort both on the theoretical

\footnotetext{
${ }^{30}$ Responses above 70 hours are treated as measurement error that would only increase noise and are excluded from the analysis. However, models that do not restrict campaign effort (time) to 70 hours per week are in line with the findings reported here and are available upon request.

${ }^{31}$ Bowler and Farrell 2011; Farrell and Scully 2007; Giebler and Wüst 2011; Wüst et al. 2006.
} 
ground as well as empirically, correlating at $0.4(\mathrm{p}<0.001)$. While the 'quantitative' measure remains an intuitive way of assessing how much an individual works to win a seat, per se it does not offer any nuances about the complexity of her campaign. In the context of post-modern campaigns - where several targeting tools and contacting options are available - candidates are compelled to fight on multiple fronts. The extent to which candidates decide to embed multiple communication channels into their campaigns is, therefore, crucial to defining the type, and scope, of the stimuli that voters experience before the election. One could indeed choose to spend a great amount of time on canvassing, but ignore other forms of contact. Therefore, our 'qualitative' measure offers further insights into whether electoral system effects extend to shaping the choice of electioneering techniques. Second, the reliance on two indicators offers a robustness check as both measures, while describing different elements of one's campaign effort, tap into the same underlying concept.

With regard to campaigning, our dependent variable is labelled as campaign focus. It is based on a survey question directly addressing the primary aim of one's campaign. This measure ranges from 0 'to attract as much attention as possible to my party' to 10 'to attract as much attention as possible to me as a candidate', offering a unique comparative insight into the kind of messages that candidates convey to the electorate through their campaign effort.

In Table 1, we show the averages and standard deviations per country for the three dependent variables. This offers an initial indication that electoral institutions might play a part in explaining this variation. For example, if we look at the most partyand candidate-centred PR systems - that is, closed list PR (Portugal) and PR-STV 
(Ireland) -, we can appreciate some suggestive evidence for it. Candidates in Ireland, on average, engage in greater campaign effort in terms of time (45 versus 28 hours) as well as complexity (4.2 versus 2.5 in campaign activities) than those in Portugal, with the former also conduct more personalised campaigns (5.6 versus 1.7$).{ }^{32}$ That said, these differences may, of course, be due to some contextual elements and need to be assessed in a rigorous way, by including possible alternative explanations.

Table 1. Descriptive Statistics on Campaign Effort and Campaign Focus

\begin{tabular}{|c|c|c|c|}
\hline & $\begin{array}{c}\text { Campaign Effort } \\
\text { (Time) }\end{array}$ & $\begin{array}{c}\text { Campaign Effort } \\
\text { (Complexity) }\end{array}$ & Campaign Focus \\
\hline & Mean (st.dev.) & & Mean (st.dev.) \\
\hline \multicolumn{4}{|l|}{ Australia } \\
\hline House & $34.7(17.1)$ & $3.6(1.6)$ & $3.1(3.1)$ \\
\hline Senate & $28.8(18.4)$ & $0.0(0.0)$ & $1.3(2.0)$ \\
\hline Canada & $45.7(20.2)$ & $4.5(0.9)$ & \\
\hline Czech Republic & $22.3(19.1)$ & & $2.7(2.8)$ \\
\hline Denmark & $35.3(19.3)$ & $3.2(1.2)$ & $4.1(3.3)$ \\
\hline Estonia & $13.9(14.9)$ & & $3.8(3.1)$ \\
\hline Finland & $25.0(19.7)$ & $1.7(1.1)$ & $4.2(3.1)$ \\
\hline Germany & $49.5(9.9)$ & $4.6(0.7)$ & $4.4(3.3)$ \\
\hline Greece & $30.8(23.0)$ & $4.0(0.9)$ & $3.9(2.3)$ \\
\hline Iceland & $19.2(17.8)$ & $1.8(1.3)$ & $1.9(2.9)$ \\
\hline Ireland & $44.6(18.5)$ & $4.2(1.0)$ & $5.6(3.0)$ \\
\hline Netherlands & $21.9(18.1)$ & $3.1(1.6)$ & $2.0(2.5)$ \\
\hline Norway & $20.3(19.3)$ & $1.9(1.5)$ & $1.3(2.1)$ \\
\hline Poland & $31.0(17.8)$ & $2.7(1.4)$ & $4.7(3.3)$ \\
\hline Portugal & $27.5(20.4)$ & $2.5(1.4)$ & $1.7(2.2)$ \\
\hline Switzerland & $12.7(11.8)$ & $2.3(1.7)$ & $3.4(2.7)$ \\
\hline
\end{tabular}

\section{Key Explanatory Variables and Controls}

We rely on survey data from a diverse set of countries, covering a variety of electoral institutions and district magnitudes. ${ }^{33}$ Among these countries, Canada uses

\footnotetext{
${ }^{32}$ Differences in the mean scores are statistically significant at $\mathrm{p}<.01$ for all three comparisons.

${ }^{33}$ The electoral system types range from the highly party-centred closed list PR (Portugal) where voters cast a single party vote to highly candidate-centred open list PR (Estonia) where voters cast a single candidate vote and PR-STV (Ireland) where voters can cast preference votes for multiple
} 
SMD to elect all members to the House of Commons, while Australia and Germany use SMD to elect a portion of legislators. ${ }^{34}$ This enables us to start by looking at the differences in the candidates' campaign activity under SMD versus PR. This initial comparison is straightforward and we capture it by coding candidates who stood in a SMD system as ' 1 ' and those who stood in a PR system as ' 0 '. This offers a first, if raw, indication of whether electoral set ups affect campaigning and electioneering.

To better gauge the nuances, we then classify electoral systems following the seminal study of Farrell and Scully ${ }^{35}$ where the concept of electoral incentives is operationalised as the cumulative score of:

i) Ballot access: the degree of party versus voter control over the ballot placement of candidates, ranging from 1 to 3 .

ii) Vote choice: the extent to which voters are able to vote for a specific candidate, ranging from 1 to 4 .

iii) District: the effect of a district type on the importance of personal reputation, ranging from 1 to 2 .

candidates. In-between we have PR systems where voters cast their ballot for the party with an option to alter candidate rankings (Iceland), where they cast preference votes with an option to vote for the party ticket (Australian Senate), and where they can cast either a candidate or a party vote (Denmark).

${ }^{34}$ The following analysis includes both the House of Representatives (plurality system) and Senate (PR system) candidates from Australia as the 2007 and 2013 survey data include an identifier for the legislative chamber. In case of Germany, however, there was no identifier for the type of candidacy available. Therefore, we included only those Bundestag candidates in the analysis who had a specific Wahlkreis identifier in the 2009 survey data as SMD candidates, since we know that they did stand for election in a plurality constituency.

${ }^{35}$ Farrell and Scully 2007. 
Higher scores across these components are indicative of a candidate-centred electoral system. Therefore, the overall index ranges from 3 to 9 , with higher values corresponding to greater incentives for candidates to cultivate a personal vote. ${ }^{36}$

As the final, yet potentially important, element of the electoral set up, we explore the role of the district magnitude in influencing the candidates' campaign behaviour. ${ }^{37}$ We do so by looking at whether the district magnitude has a direct, independent effect on campaign behaviour, but also whether its effect is being conditioned by vote choice. The value of personal reputation should decline as district magnitude increases in systems where voters cast party-based votes such as closed list PR, whereas it should increase as district magnitude increases in systems where voters cast candidate-based votes such as open list PR. The measure is operationalised as the natural logarithm of the number of seats allocated in the constituency. ${ }^{38}$ The use

\footnotetext{
${ }^{36}$ See the online appendix Table A1 for a detailed breakdown of how the different countries and their electoral systems are coded.

${ }^{37}$ We also ran models where district magnitude was not used alongside smd and electoral incentives. Estimates from these models are in line with the findings reported here and available upon request.

${ }^{38} \mathrm{We}$ acknowledge that population density would be a more fine-grained measure to address the impact of the district size on the candidates' campaign strategy. Geographical data to systematically match constituencies in our data with information on population density is, however, not available. That said, district magnitude does represent a good alternative for capturing the district size effect. As noted by Taagepera and Shugart (1989), district magnitude is calibrated on district size where size "refers to the number of voters in an electoral district or the geographical extent of a district".
} 
of a natural logarithm is the conventional practice, ${ }^{39}$ and particularly useful to correct the skewed nature of the district magnitude in our data. ${ }^{40}$

Finally, we control for several elements that previous studies have shown to be relevant to explaining campaign effort and focus. ${ }^{41}$ First and foremost, we account for campaign marginality - that is, the chance of being elected. Clearly, the higher the foreseen chance of success, the stronger the incentive for electioneering. Moreover, candidates who believe that they are unlikely to get elected are likely to put less effort into their own campaign and opt for a more party-focused campaign strategy to build a profile within their party, with consequent implications for campaigning. We operationalise the likelihood of success as the candidates' selfperceived likelihood of success before their campaign started, ranging from 1 'I could not win' to 5 'I could not lose'. Second, the nature of the candidate's campaign may be influenced by her relationship with her party. Namely, the further away a candidate's own positions are from those of her party, the more likely she is to conduct a campaign with a personalised focus and to put in extra campaign effort to get her own political views across. We measure ideological distance as the absolute difference between the left-right position of the candidate and that of her party (as perceived by the candidate). It ranges from 0 'no difference' to 10 'maximum difference'. Left-right placement is not only the most comparable measure for a study of this sort, but also the best available shortcut for aggregating multiple policy

\footnotetext{
${ }^{39}$ Benoit 2002.

${ }^{40}$ Our sample includes data from the Netherlands where all 150 House of Representatives seats are allocated in a single nation-wide constituency.

${ }^{41}$ Bowler and Farrell 2011; Gibson and McAllister 2006; Zittel and Gschwend 2008; Zittel 2009.
} 
positions. ${ }^{42}$ Third, we look at the candidates' political experience by accounting for incumbency (past MP) and their position within the party (party hierarchy). Past MP is coded 1 if the candidate has been a member of parliament before and 0 if not, and party hierarchy is coded 1 if she has held national party office or been employed by it and 0 if not. We expect candidates with such experience to undertake more intensive and personalised campaigns. Fourth, we control for the candidates' proximity to voters by separating those living in the constituency where they stand for election (coded 1) from the rest (coded 0 ) on the premise that the former are more invested in constituency matters and, therefore, push harder to get elected through a stronger campaign effort and more personalised campaign focus. ${ }^{43}$

\section{Empirical Strategy}

Given the different data structure of our dependent variables, different estimation techniques are used to analyse variation in the different aspects of campaign behaviour. With regard to the 'quantitative' measure of electioneering, time, we use OLS, as the dependent variable is measured in hours per week. Similarly, OLS is implemented to empirically address campaign focus. Conversely, the 'qualitative' index of campaign effort is analysed using ordered probit, given the structure of the variable. In line with the key explanatory elements described above, we run three sets of models for each dependent variable: the first set (Models 1, 4, and 7) accounts for electoral mechanisms by using the simple plurality dummy, the second set (Models 2, 5, and 8) uses the electoral incentives index, and the final third set (Models 3, 6, and 9) explores the interactive effects of district magnitude and vote

\footnotetext{
${ }^{42}$ Benoit and Laver 2007.

${ }^{43}$ Górecki and Marsh 2012; Górecki and Marsh 2014.
} 
choice. Finally, model specifications take into account the country-specific contexts of electoral politics; therefore, we include country dummies as a control. ${ }^{44}$ This accounts for any country-specific effects beyond the electoral institutions.

\section{Empirical Analysis}

We begin by addressing the effects of electoral institutions on electioneering. The first set of models (1-3), reported in Table 2, explain variation in campaign effort (time). In line with our theoretical expectations, candidate-centred electoral systems seem to provide an incentive for candidates to campaign harder. The coefficient of SMD in Model 1 shows a difference of 11 hours per week between plurality and PR systems as the former produce higher intensity campaign effort. When we look at more nuances of the electoral mechanisms in Model 2, we observe an average increase of 3 hours per week in campaign effort as we move from those who have weaker systemic incentives to cultivate a personal vote to those who have stronger incentives to do so. Consistently across the different models, a significant effect of electoral institutions exists on the intensity of candidates' campaign effort.

\footnotetext{
${ }^{44}$ We prefer this approach to multi-level modelling as the structure of the data does not satisfy the 30/30 rule (see Kreft 1996). Estimates from multi-level models that have countries as a Level-2 variable are, however, similar to the findings reported here and presented in the online appendix Table A3. We also ran multi-level models with parties as a Level-2 variable; their estimates are in line with the findings reported here and presented in the online appendix Table A4.
} 
Table 2. Explaining Variation in Campaign Effort (Time)

\begin{tabular}{|c|c|c|c|}
\hline & \multicolumn{3}{|c|}{ Campaign Effort (Time) } \\
\hline & Model 1 & Model 2 & Model 3 \\
\hline SMD & $10.87 *(5.40)$ & & \\
\hline Electoral Incentives & & $2.72 *(1.35)$ & \\
\hline District Magnitude & $-1.23 * *(0.37)$ & $-1.23 * *(0.37)$ & \\
\hline \multicolumn{4}{|l|}{ Personal Vote $*$ DM } \\
\hline Personal Vote (1) & & & $-2.98 *(1.21)$ \\
\hline Personal Vote (2) & & & $-1.90(1.43)$ \\
\hline Personal Vote (3) & & & $-1.71 * *(0.39)$ \\
\hline Personal Vote (4) & & & $1.48(1.05)$ \\
\hline Likelihood of Success & $3.84 * *(0.25)$ & $3.84 * *(0.25)$ & $3.82 * *(0.25)$ \\
\hline Ideological Distance & $0.04(0.20)$ & $0.04(0.20)$ & $0.03(0.20)$ \\
\hline Past MP & $2.85 * *(0.96)$ & $2.85 * *(0.96)$ & $2.76 * *(0.96)$ \\
\hline Party Hierarchy & $3.45 * *(0.56)$ & $3.45 * *(0.56)$ & $3.45 * *(0.56)$ \\
\hline Constituency & $-0.28(1.07)$ & $-0.28(1.07)$ & $-0.38(1.08)$ \\
\hline Constant & $14.03 *(5.45)$ & $0.45(12.09)$ & $24.48 * *(1.49)$ \\
\hline Country fixed-effects & yes & yes & yes \\
\hline Countries & 15 & 15 & 15 \\
\hline Observations & 5158 & 5158 & 5158 \\
\hline R-squared & 0.31 & 0.31 & 0.32 \\
\hline
\end{tabular}

Table 2 also shows that district magnitude has a negative effect on the dependent variable. A shift from the smallest to the largest constituency corresponds to a 6 hours per week decline in candidates' predicted campaign effort (based on estimates in Models 1 and 2). As indicated by Model 3, the negative effect of district magnitude is, however, influenced by vote choice. It is strongest in electoral systems where voters are required to cast their ballot for a party list. Clearly, the extent to which electoral mobilisation is promoted through candidates' campaign effort is substantially different across the various electoral systems. The more candidatecentred the electoral set up, and the smaller the district magnitude, the higher the intensity of candidates' campaign effort, ceteris paribus.

As expected, however, campaign effort is not just a function of the electoral set up. At the individual level, we find that candidates who are confident in their electoral 
chances ahead of their campaign conduct significantly higher intensity campaigns than candidates who did not expect to get elected. Predicted campaign effort rises from 18 hours per week for candidates who thought that they had no chance of getting elected to 34 hours per week for candidates who felt certain to get elected prior to campaigning. In addition, small positive effects - that is, around 3 hours per week - are associated with both political experience variables. At the same time, we do not find ideological distance or proximity to voters to play a significant role in affecting how much time candidates choose to spend on their campaign.

With regard to the qualitative measure of candidates' campaign effort, we find that the same patterns are visible when explaining the complexity of the candidates' campaign effort (Table 3). In line with our theoretical expectations, candidates in SMD systems tend to use a wider range of campaign activities than their counterparts in PR systems, while the positive effect associated with electoral incentives indicates that candidates undertake more complex campaigns when the electoral set up offers stronger incentives to cultivate a personal vote. In addition, larger district magnitude coincides with the use of a narrower range of campaign activities and the largest negative effect is again observed in electoral systems where voters have to cast their ballot for a party list. These findings are in line with what we observed when looking at the 'quantitative' aspect of campaign effort, reaffirming that higher levels of campaign effort are associated with more candidatecentred electoral set ups and smaller district magnitudes. 
Table 3. Explaining Variation in Campaign Effort (Complexity)

\begin{tabular}{|c|c|c|c|}
\hline & \multicolumn{3}{|c|}{ Campaign Effort (Complexity) } \\
\hline & Model 4 & Model 5 & Model 6 \\
\hline SMD & $6.05 * *(0.28)$ & & \\
\hline Electoral Incentives & & $1.51 * *(0.07)$ & \\
\hline District Magnitude & $-0.09 *(0.03)$ & $-0.09 *(0.03)$ & \\
\hline Personal Vote * DM & & & \\
\hline Personal Vote (1) & & & $-0.24 * *(0.08)$ \\
\hline Personal Vote (2) & & & $-0.03(0.13)$ \\
\hline Personal Vote (3) & & & $-0.13 * *(0.05)$ \\
\hline Personal Vote (4) & & & $0.15 * *(0.06)$ \\
\hline Likelihood of Success & $0.21 * *(0.02)$ & $0.21 * *(0.02)$ & $0.21 * *(0.02)$ \\
\hline Ideological Distance & $0.05 *(0.02)$ & $0.05 *(0.02)$ & $0.05 *(0.02)$ \\
\hline Past MP & $0.27 * *(0.06)$ & $0.27 * *(0.06)$ & $0.28 * *(0.06)$ \\
\hline Party Hierarchy & $0.31 * *(0.05)$ & $0.31 * *(0.05)$ & $0.31 * *(0.05)$ \\
\hline Constituency & $0.09(0.07)$ & $0.09(0.07)$ & $0.08(0.02)$ \\
\hline /cut1 & $4.60(0.24)$ & $12.16(0.60)$ & $-1.42(0.17)$ \\
\hline /cut2 & $5.43(0.24)$ & $12.99(0.60)$ & $-0.59(0.17)$ \\
\hline /cut3 & $6.07(0.25)$ & $13.63(0.60)$ & $0.05(0.17)$ \\
\hline /cut4 & $6.61(0.25)$ & $14.17(0.60)$ & $0.60(0.17)$ \\
\hline /cut5 & $7.01(0.25)$ & $14.57(0.60)$ & $1.00(0.17)$ \\
\hline Country fixed-effects & yes & yes & yes \\
\hline Countries & 13 & 13 & 13 \\
\hline Observations & 3032 & 3032 & 3032 \\
\hline Log Pseudolikelihood & -4813 & -4813 & -4809 \\
\hline
\end{tabular}

Robust standard errors in parentheses; $* * \mathrm{p}<0.01, * \mathrm{p}<0.05$.

Personal vote: (1) - vote for list only; (2) - vote for list or candidate, list vote dominates;

(3) vote for list or candidate, candidate vote dominates; (4) vote for candidate only.

Figure 1 illustrates the effects associated with electoral institutions, showing how candidates' likelihood of undertaking campaigns of high and low complexity is conditioned by electoral incentives (Figure 1a) and district magnitude (Figure 1b). Figure 1a highlights well how the probability of high campaign complexity - that is, maximum score for campaign complexity - increases as we move from a partycentred electoral system to a candidate-centred one, while the opposite is true for candidates' likelihood of conducting low complexity campaigns. In a similar vein, Figure $1 \mathrm{~b}$ shows that the effects of district magnitude go in the opposite direction. While lower district magnitude leads to a higher likelihood of implementing a broad array of campaign tools, larger districts depress the use of multiple campaign tools. These effects are, however, of notably smaller scale. A shift from the smallest to 
largest district brings about an $8 \%$ increase in candidates' likelihood of conducting a low complexity campaign (from $8 \%$ to $16 \%$ ) and a $9 \%$ decline in their likelihood of conducting a high complexity campaign (from $24 \%$ to $15 \%$ ). In sum, candidatecentred electoral set ups and smaller district magnitudes tend to propel higher mobilisation efforts, in terms of campaign intensity as well as complexity.

Figure 1. Effects of Electoral Institutions on Campaign Effort (Complexity)

Figure 1a. Effect of Electoral Incentives on Campaign Effort (Complexity)

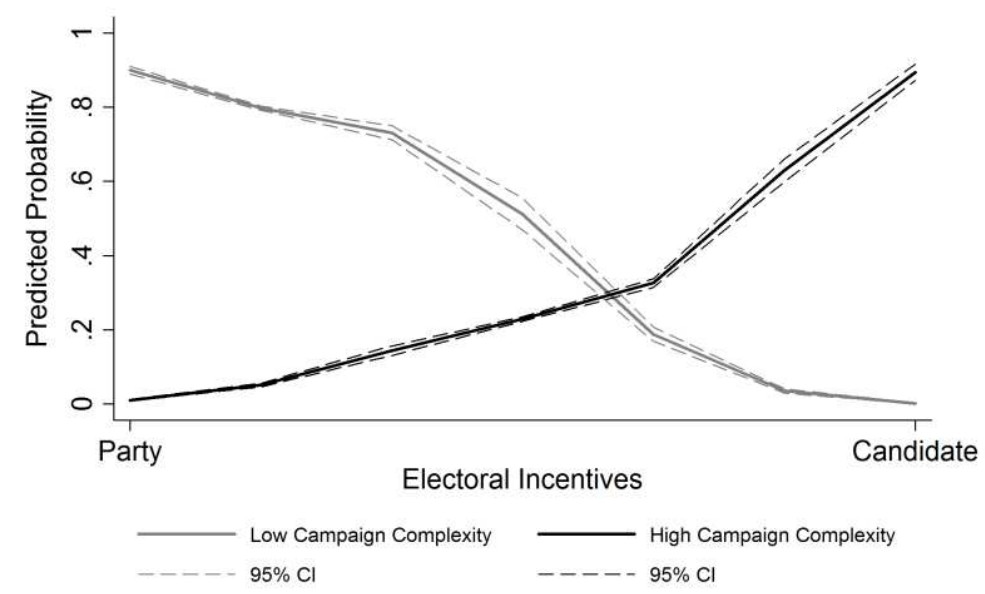

Figure 1b. Effect of District Magnitude on Campaign Effort (Complexity)

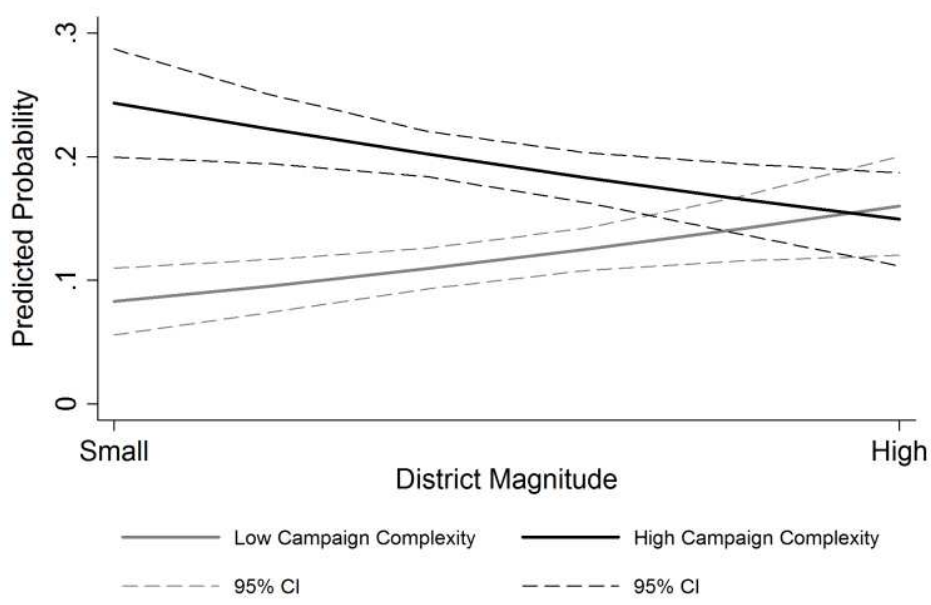


When district magnitude and electoral incentives are looked at separately, we can appreciate their independent effects on campaign effort. When we assess their joint effects in Models 3 and 6, however, we find some evidence to confirm the intuition of Carey and Shugart that the incentives to cultivate a personal vote decline in closed list systems when district magnitude increases and that the opposite happens in open list systems. ${ }^{45}$ Nevertheless, there is not sufficient proof that such interactions exist: while the direction of the coefficients is in line with the expectations, the associated confidence intervals overlap in Model 3 and the significance of certain categories in Model 6 have little meaningful value. ${ }^{46}$

Having seen how electoral institutions affect both the 'quantity' and 'quality' of campaign effort, we move to assessing whether the electoral set up also has an effect on the extent to which the candidates' campaign messages focus on themselves versus their party. Table 4 presents the outputs from the analyses of campaign focus. The findings are clear and consistent: candidate-centred electoral set ups incentivise candidates to opt for a more candidate-focused campaign strategy. The coefficient of SMD in Model 7 shows a 2.2-point difference between SMD and PR systems, with the former producing more personalised electoral campaigns. When looking at electoral systems in a more nuanced manner in Model 8, we observe an average 0.6point increase in the extent to which candidates prioritise their own (versus party) image when we move from those who have weaker systemic incentives to cultivate a personal vote to those who have stronger incentives to do so. While quite modest in

\footnotetext{
${ }^{45}$ Carey and Shugart 1995.

${ }^{46}$ Ai and Norton 2003; Norton, Wang, and Ai 2004.
} 
size, the effect is robust across the different specifications of the key independent variable. On the contrary, the evidence that the district magnitude has an effect on campaign focus is limited. We do not observe a significant independent effect for district magnitude in Models 7 and 8, with a significant negative effect being present only when focusing on two categories of vote choice in Model 9. Once again, the evidence of a potential interaction effect between electoral incentives and district magnitude, albeit in line with the expectations, is empirically weak.

Table 4. Explaining Variation in Campaign Focus

\begin{tabular}{|c|c|c|c|}
\hline & \multicolumn{3}{|c|}{ Campaign Focus } \\
\hline & Model 7 & Model 8 & Model 9 \\
\hline SMD & $2.21 * *(0.56)$ & & \\
\hline Electoral Incentives & & $0.55 * *(0.14)$ & \\
\hline District Magnitude & $-0.04(0.06)$ & $-0.04(0.06)$ & \\
\hline Personal Vote $*$ DM & & & \\
\hline Personal Vote (1) & & & $-.23 *(0.11)$ \\
\hline Personal Vote (2) & & & $-.37 *(0.16)$ \\
\hline Personal Vote (3) & & & $-.07(0.08)$ \\
\hline Personal Vote (4) & & & $.14(0.14)$ \\
\hline Likelihood of Success & $0.64 * *(0.03)$ & $0.64 * *(0.03)$ & $.64 * *(0.03)$ \\
\hline Ideological Distance & $0.22 * *(0.03)$ & $0.22 * *(0.03)$ & $.21 * *(0.03)$ \\
\hline Past MP & $-0.00(0.12)$ & $-0.00(0.12)$ & $-.03(0.12)$ \\
\hline Party Hierarchy & $-0.09(0.08)$ & $-0.09(0.08)$ & $-.09(0.08)$ \\
\hline Constituency & $0.06(0.13)$ & $0.06(0.13)$ & $.04(0.13)$ \\
\hline Constant & $-0.71(0.56)$ & $-3.48 * *(1.24)$ & $1.44 * *(0.20)$ \\
\hline Country fixed-effects & yes & yes & yes \\
\hline Countries & 14 & 14 & 14 \\
\hline Observations & 6375 & 6375 & 6375 \\
\hline R-squared & 0.20 & 0.20 & 0.20 \\
\hline
\end{tabular}

Robust standard errors in parentheses; $* * \mathrm{p}<0.01, * \mathrm{p}<0.05$.

Personal vote: (1) - vote for list only; (2) - vote for list or candidate, list vote dominates; (3) vote for list or candidate, candidate vote dominates; (4) vote for candidate only.

At the individual level, we find that candidates who are more confident in their electoral chances conduct more candidate-focused campaigns, as do those who feel ideologically more distant from their party. At the same time, there is no evidence 
that the candidates' previous political experience or proximity to voters plays a role in influencing their campaign focus.

In summary, the empirical analysis indicates clearly that electoral institutions are significant predictors for electioneering practices after all, leading to the rejection of the claim that candidates work equally hard irrespective of the electoral system type. However, when it comes to assessing the effects of electoral institutions on campaigning, the evidence is more multifaceted. More candidate-centred electoral systems do lead to more personalised campaign messages as expected, but district magnitude does not have an independent effect on the campaign focus. A significant negative effect for the district magnitude is only found where voters either have to or tend to cast their ballot for a party. No matter how large (or small) the district, candidates concentrate on promoting their own personal image if the electoral set up encourages or requires voters to cast personal/preference votes.

The disjuncture between previous findings from the elite side and the voter side literature is resolved when looking at the first-order parliamentary elections, and when the complexity of electioneering and campaigning are taken into account.

\section{Conclusions}

In this article we have explored the effects of electoral institutions on the campaign behaviour of candidates running for office at first-order parliamentary elections. While studies of the European elections have provided us with valuable insights into the impact of electoral institutions on individual-level campaigning during secondorder elections, we have taken a first step to extend this type of analysis to the arena 
that still remains most crucial for political competition among candidates and parties, as well as for the voters. Our study contributes to the wider debate on the role of electoral institutions in promoting political engagement and voter mobilisation by showing that smaller districts in candidate-centred electoral systems maximise the likelihood of voters experiencing higher intensity campaigns.

Campaigns provide voters with the knowledge they need to make an informed vote choice and increase the likelihood of electoral participation. ${ }^{47}$ The engineering of electoral institutions is often inspired by considerations on what systemic effects electoral rules will produce. Here, we have shed some light on the strategic effects of electoral institutions by showing that electoral systems have an independent impact on elite-level behaviour. Where electoral rules allow for candidate-based vote choice(s), candidates tend to put forward more intense and complex campaign efforts as well as campaign along less partisan lines. This goes hand in hand with what is found by studies of electoral institutions and styles of representation, ${ }^{48}$ but against what we know from studies of second-order elections, as the latter have pointed to a weak link between electoral institutions and the candidates' campaign behaviour.

Our study can reconcile the supply, elite side with what is observed by voter studies, suggesting that the second-order European elections may not be the best venue for exploring the effects of electoral institutions, as they are likely to be masked by little variation in the independent variables and limited in the sample of candidates. The cross-national CCS project, taken together with other compatible candidate surveys,

\footnotetext{
${ }^{47}$ Green, Aronow, and McGrath 2013; Green and Gerber 2008; Nickerson, Friedrichs, and King 2006.

${ }^{48}$ Carey 2007; Olivella and Tavits 2014.
} 
can overcome the limits of our current understanding of parliamentary candidates' campaign behaviour, their intentions and attitudes. This collection of candidate studies enables us to extend the analysis of how electoral institutions influence candidates' campaign behaviour to first-order parliamentary elections. In addition, it offers nuances on how candidates mobilise voters by going beyond voters' reported contact. Voter studies usually rely on questions on door-to-door and/or telephone contact, ${ }^{49}$ leaving aside the more recent and upcoming forms of campaign tools like contact via Internet. Our qualitative measure of electioneering encompasses a wide array of means which candidates may use to reach the voters.

We find that electoral institutions do shape the candidates' campaign behaviour in the run up to first-order parliamentary elections, both in terms of campaign effort and campaign focus. The extent to which voters are likely to experience campaign stimuli is closely related to electoral institutions as candidates' campaign effort tends to be more intense, as well as complex, under candidate-centred electoral institutions than under party-centred ones. Equally, candidates seem to tailor their campaign message to the electoral context, as the extent to which it tends to be candidatefocused is greater under candidate-centred electoral set ups. While the debate on the personalisation of electoral campaigns has, to date, focused mostly on the role of party leaders, this indicates that it should also feature the candidate side more prominently. All in all, the findings suggest that the impact of electoral institutions on campaigns is more far-reaching than what the state of the art describes. Both the amount and type of campaign stimuli that voters tend to experience is closely related to electoral institutions.

\footnotetext{
${ }^{49}$ Karp, Banducci, and Bowler 2008.
} 
In sum, our findings broaden the understanding of how electoral institutions affect campaign practices in the run up to first-order parliamentary elections. It is generally accepted that electoral campaigns are shaped by country-specific dynamics as well as party- and candidate-specific characteristics. The empirical evidence offered here adds electoral institutions to this list. 


\section{REFERENCES}

Ai, Chunrong, and Edward C. Norton. 2003. Interaction Terms in Logit and Probit Models. Economics Letters 80:123-129.

Alvarez, Michael, and Betsy Sinclair. 2012. Electoral Institutions and Legislative Behaviour: the Effects of Primary Processes. Political Research Quarterly $63: 544-557$.

Benoit, Kenneth. 2002. The Endogeneity Problem in Electoral Studies: A Critical Re-Examination of Duverger's Mechanical Effect. Electoral Studies 21:3546.

Benoit, Kenneth, and Michael Laver. 2007. Estimating Party Policy Positions: Comparing Expert Surveys and Hand-Coded Content Analysis. Electoral Studies 26:90-107.

Bowler, Shaun, and David Farrell. 1992. The Study of Election Campaigning. In Electoral Strategies and Political Marketing, edited by Shaun Bowler and David Farrell, 1-23. New York: St. Martin’s Press.

Bowler, Shaun, and David Farrell. 2011. Electoral Institutions and Campaigning in Comparative Perspective: Electioneering in European Parliament Elections. European Journal of Political Research 50:668-688. 
Carey, John. 2007. Competing Principals, Political Institutions, and Party Unity in Legislative Voting. American Journal of Political Science 51:92-107.

Carey, John, and Matthew Shugart. 1995. Incentives to Cultivate a Personal Vote: a Rank Ordering of Electoral Formulas. Electoral Studies 14:417-439.

Colomer, Josep M. 2011. Personal Representation: The Neglected Dimension of Electoral Systems. Colchester: ECPR Press.

Cox, Gary. 1997. Making Votes Count: Strategic Coordination in the World's Electoral Systems. Cambridge: Cambridge University Press.

Dalton, Russell. 2008. Citizen Politics: Public Opinion and Political Parties in Advanced Industrial Democracies. Washington: Congressional Quarterly Press.

Farrell, David. 2006. Political Parties in a Changing Campaign Environment. In Handbook of Party Politics, edited by Richard Katz and William Crotty, 122133. London: SAGE.

Farrell, David. 2011. Electoral Systems: A Comparative Introduction. Basingstoke: Palgrave Macmillan.

Farrell, David, and Rüdiger Schmitt-Beck. 2002. Do Political Campaigns Matter? Campaign Effects in Elections and Referendums. London: Routledge. 
Farrell, David, and Roger Scully. 2007. Representing Europe's Citizens? Electoral Institutions and the Failure of Parliamentary Representation in the European Union. Oxford: Oxford University Press.

Farrell, David, and Paul Webb. 2000. Political Parties as Campaign Organizations. In Parties without Partisans: Political Change in Advanced Industrial Democracies, edited by Richard Dalton and Martin Wattenberg, 102-128. Oxford: Oxford University Press.

Fauvelle-Aymar, Christine, and Michael Lewis-Beck. 2008. TR versus PR: Effects of the French Double Ballot. Electoral Studies 27:400-406.

Fieldhouse, Edward, and David Cutts. 2009. The Effectiveness of Local Party Campaigns in 2005: Combining Evidence from Campaign Spending and Agent Survey Data. British Journal of Political Science 39:367-388.

Gallagher, Michael, and Paul Mitchell. 2005. The Politics of Electoral Systems. Cambridge: Cambridge University Press.

Gibson, Rachel, and Ian McAllister. 2006. Does Cyber-Campaigning Win Votes? Online Communication in the 2004 Australian Election. Journal of Elections, Public Opinion \& Parties 16:243-263. 
Giebler, Heiko, and Andreas Wüst. 2011. Campaigning on an Upper Level? Individual Campaigning in the 2009 European Parliament Elections in its Determinants. Electoral Studies 30:53-66.

Górecki, Maciej A., and Michael Marsh. 2014. A Decline of 'Friends and Neighbours Voting' in Ireland? Local Candidate Effects in the 2011 Irish 'Earthquake Election'. Political Geography 41:11-20.

Górecki, Maciej A., and Michael Marsh. 2012. Not Just 'Friends and Neighbours': Canvassing, Geographic Proximity and Voter Choice. European Journal of Political Research 51:563-582.

Green, Donald P., Peter M. Aronow, and Mary C. McGrath. 2013. Field Experiments and the Study of Voter Turnout. Journal of Elections, Public Opinion \& Parties 23:27-48.

Green, Donald P., and Alan S. Gerber. 2008. Get Out The Vote: How to Increase Voter Turnout. Washington: Brookings Institute Press.

Karp, Jeffrey, and Susan Banducci. 2007. Party Mobilization and Political Participation in New and Old Democracies. Party Politics 13:217-234.

Karp, Jeffrey, Susan Banducci, and Shaun Bowler. 2008. Getting Out the Vote: Party Mobilization in a Comparative Perspective. British Journal of Political Science 38:91-112. 
Karp, Jeffrey, Jack Vowles, Susan Banducci, and Todd Donovan. 2002. Strategic Voting, Party Activity, and Candidate Effects: Testing Explanations for Split Voting in New Zealand's New Mixed System. Electoral Studies 21:1-22.

Kreft, Ita. 1996. Are Multilevel Techniques Necessary? An Overview, Including Simulation Studies. California State University. Los Angeles.

Marsh, Michael. 2000. Candidate Centered but Party Wrapped: Campaigning in Ireland under STV. In Elections in Australia, Ireland and Malta under the Single Transferable Vote, edited by Shaun Bowler and Bernard Grofman, 114-130. Ann Arbor, Michingan: The University of Michigan Press.

McAllister, Ian. 2002. Calculating or Capricious? The New Politics of Late Deciding Voters. In Do Political Campaigns Matter? Campaign Effects in Elections and Referendums, edited by David Farrell and Rüdiger Schmitt-Beck, 22-40. London: Routledge.

Nickerson, David W., Ryan D. Friedrichs, and David C. King. 2006. Partisan Mobilization Campaigns in the Field: Results from a Statewide Turnout Experiment in Michigan. Political Research Quarterly 59:85-97.

Norris, Pippa. 2004. Electoral Engineering: Voting Rules and Political Behavior. Cambridge: Cambridge University Press. 
Norris, Pippa, and Ronald Inglehart. 2001. Cultural Obstacles to Equal Representation. Journal of Democracy 12:126-140.

Norton, Edward C., Hua Wang, and Chunrong Ai. 2004. Computing Interaction Effects and Standard Errors in Logit and Probit Models. Stata Journal 4:154167.

Olivella, Santiago, and Margit Tavits. 2014. Legislative Effects and Electoral Mandates. British Journal of Political Science 44:301-321.

Shugart, Matthew. 2001. 'Electoral Efficiency' and the Move to Mixed-Member Systems. Electoral Studies 20:173-193.

Taagepera, Rein, and Matthew Shugart. 1989. Seats and Votes: The Effects and Determinants of Electoral Systems. New Haven: Yale University Press.

Wüst, Andreas M., Hermann Schmitt, Thomas Gschwend, and Thomas Zittel. 2006. Candidates in the 2005 Bundestag Election: Mode of Candidacy, Campaigning and Issues. German Politics 15:420-438.

Zittel, Thomas, and Thomas Gschwend. 2008. Individualised Constituency Campaigns in Mixed-Member Electoral Systems: Candidates in the 2005 German Elections. West European Politics 31:978-1003. 
Zittel, Thomas. 2009. Lost in Technology? Political Parties and the Online Campaigns of Constituency Candidates in Germany's Mixed Member Electoral System. Journal of Information Technology \& Politics 6:298-311. 